\title{
Carta Abierta
}

Nota: Por tratarse del libro Prosas y versos de José Asunción Silva, segundo volumen de la Biblioteca de Clásicos DE AMÉRI$C A$, de que nos ocupamos en este número de la revista, publicamos la siguiente carta, en la cual da su parecer el más alto crítico literario de Colombia, a quien se lo agradecemos de todo corazón.

La EdtTorial

Bogotá, febrero de 1943.

Señor don Carlos García-Prada.

(Seattle), Washington.

Mi querido amigo:

Muy agradable sorpresa me produjo el recibo de su excelente selección de José Asunción Silva. La edición es muy elegante, y la mejor que se ha hecho del poeta; las piezas están muy bien escogidas y ha dado usted entrada a composiciones que no figuran en otras ediciones y que son dignas de recuerdo. He leído con placer el estudio preliminar, que me parece lo mejor que usted ha escrito, por la manera elevada como trata usted el tema, sin incurrir en exageraciones y $\sin$ repetir consejas erróneas ni vulgaridades que desentonan en un trabajo serio. No ha creído usted necesario, para ensalzar a Silva, presentarlo como un nuevo Ovidio, perdido en medio de los salvajes sármatas, ni lo ha presentado como objeto de la persecución de sus compatriotas, muchos de los cuales lo quisieron y admiraron, 
ni de la burlona incomprensión de una sociedad en donde siempre ocupó puesto distinguido. $\mathrm{Ha}$ tributado usted un justo homenaje a la memoria del gran poeta y ha prestado un gran servicio al público lector, pues las ediciones anteriores se han ido agotando. Felicito a usted cordialmente por este nuevo servicio a las letras patrias y quedo su afectísimo amigo,

(firmado), Antonio Gómez Restrepo 